\title{
Origanum vulgare L. essential oil as inhibitor of potentially toxigenic Aspergilli
}

\author{
Efetividade do óleo essencial de orégano (Origanum vulgare L., Lamiaceae) como \\ inibidor do crescimento de espécies de Aspergillus potencialmente toxigênicas
}

\author{
Teresa Cristina MITCHELL ${ }^{1}$, Tânia Lúcia Montenegro STAMFORD ${ }^{1}$, \\ Evandro Leite de SOUZA ${ }^{1 \star}$, Edeltrudes de Oliveira LIMA², Egberto Santos CARMO ${ }^{2}$
}

\begin{abstract}
Origanum vulgare L. essential oil has been known as an interesting source of antimicrobial compounds to be applied in food conservation. In this study, the effect of $O$. vulgare essential on the growth of A. flavus, A. parasiticus, A. fumigatus, A. terreus and A. ochraceus was assessed. The essential oil had a significant inhibitory effect on all assayed fungi. MIC was $0.6 \mu \mathrm{L} \cdot \mathrm{mL}^{-1}$ for all fungi, while MFC was in the range of 1.25-2.5 $\mu \mathrm{L} . \mathrm{mL}^{-1}$. The radial mycelial growth of A. flavus and A. parasiticus was strongly inhibited over 14 days at $0.6,1.25$ and $2.5 \mu \mathrm{L} . \mathrm{mL}^{-1}$ of oil in solid medium. The mycelial mass of all fungi was inhibited over $90 \%$ at 0.6 and $0.3 \mu \mathrm{L} \cdot \mathrm{mL}^{-1}$ in liquid medium, while it was $100 \%$ at $1.25 \mu \mathrm{L} \cdot \mathrm{mL}^{-1}$. The oil in a range of concentrations $\left(0.6\right.$ to $\left.2.5 \mu \mathrm{L} \cdot \mathrm{mL}^{-1}\right)$ was effective in inhibiting the viability and spores germination in a short time of exposure. The main morphological changes caused by the essential oil in $A$. parasiticus observed under light microscopy were absence of conidiation, leakage of cytoplasm, loss of pigmentation, and disrupted cell structure. These results demonstrated that $O$. vulgare essential oil produced a significant fungitoxic effect supporting its possible rational use as anti-mould compound in food conservation.

Keywords: Origanum vulgare L.; anti-mould activity; Aspergillus; biocontrol.
\end{abstract}

\section{Resumo}

O óleo essencial de Origanum vulgare L. tem sido reconhecido como uma interessante fonte de compostos antimicrobianos para ser aplicado na conservação de alimentos. Neste estudo, avaliou-se o efeito do óleo essencial de O. vulgare sobre o crescimento de A. flavus, A. parasiticus, A. fumigatus, A. terreus e A. ochraceus. O óleo essencial apresentou um significante efeito inibitório sobre todos os fungos ensaiados. A CIM foi $0,6 \mu \mathrm{L} \cdot \mathrm{mL}^{-1}$ para todos os fungos, enquanto a CFM variou entre 1,25-2,5 $\mu \mathrm{L} \cdot \mathrm{mL}^{-1}$. O crescimento micelial radial de A. flavus e $A$. parasiticus foi fortemente inibido ao longo de 14 dias pelo óleo essencial nas concentrações de 0,$6 ; 1,25 ; \mathrm{e} 2,5 \mu \mathrm{L} . \mathrm{mL}^{-1} \mathrm{em} \mathrm{meio}$ sólido. O óleo essencial a 0,6 e $0,3 \mu \mathrm{L} \cdot \mathrm{mL}^{-1}$ inibiu o aumento da massa micelial de todos os fungos em valores superiores a $90 \%$ em meio líquido, enquanto a $1,25 \mu \mathrm{L} \cdot \mathrm{mL}^{-1}$, a inibição foi de $100 \%$. O óleo essencial em variadas concentrações $\left(0,6-2,5 \mu \mathrm{L} . \mathrm{mL}^{-1}\right)$ inibiu a viabilidade e germinação dos esporos fúngicos em um curto tempo de exposição. As principais alterações morfológicas provocadas pelo óleo essencial em A. parasiticus, observadas sob microscopia óptica, foram ausência de conidiação, perda de citoplasma, perda de pigmentação e ruptura de estrutura celular. Estes resultados demonstraram que o óleo essencial de O. vulgare exerce um significante efeito fungitóxico, suportando seu uso racional como agente antifúngico na conservação de alimentos.

Palavras-chave: Origanum vulgare L.; atividade antifúngica; Aspergillus; biocontrole.

\section{Introduction}

Fungi are significant destroyers of foodstuffs during storage resulting in a reduction in quality and quantity, as well as rendering them unfit for human consumption (ATANDA; AKPAN; OLUWAFEMI, 2007). Some Aspergillus species are xerophilic fungi, which are responsible for many cases of food and feed contamination all over the world (KUMAR et al., 2007).

The presence of Aspergilli in foods is toxicologically significant since some of them produce mycotoxins known as potential hazard for human and animal health (RASOOLI; OWLIA, 2005). Mycotoxin-producing Aspergilli are widely distributed in nature and frequently contaminate human food resources (SAMAPUNDO et al., 2007).
Aflatoxins- $B_{1}, B_{2}, G_{1}, G_{2}$ (produced by $A$. flavus and A. parasiticus), aspergillic and hidroxiaspergillic acid (produced by $A$. flavus), ascladiol (produced by A. clavatus), gliotoxin (produced by A. fumigatus, A. chavalieri and A. terreus), austamide (produced by $A$. usutus), ochratoxins (produced by A. ochraceus), oxalic acid (produced by A. flavus and A. glaucus), and terreic acid (produced by $A$. terreus) are some mycotoxins produced by Aspergillus species in foods when exposed to suitable conditions (OVERY et al., 2003; SALEEMULLAH; KHALIL; SHAH, 2006).

Chemicals are used to inhibit the fungal growth in/on foods, but the negative consumer perception of chemical preservatives

Recebido para publicação em 29/7/2008

Aceito para publicação em 14/6/2009 (003730)

${ }^{1}$ Departamento de Nutrição, Universidade Federal da Paraíba - UFPB, CEP 58059-900, João Pessoa - PB, Brasil, E-mail: evandroleitesouza@ccs.ufpb.br

${ }^{2}$ Departamento de Ciências Farmacêuticas, Universidade Federal da Paraíba - UFPB, CEP 58059-900, João Pessoa - PB, Brasil

${ }^{*}$ A quem a correspondência deve ser enviada 
drives attention toward natural alternatives (RASOOLI; OWLIA, 2005). Recently, the antimicrobial potential of essential oils has been of great interest in both academia and food industry since their possible use as natural additives emerged from a growing tendency to replace synthetic additives (SAMAPUNDO et al., 2007; TZORTZAKIS; ECONOMAKIS, 2007). Many studies worldwide have showed the efficacy of essential oils and extracts of various plants in inhibiting the growth of spoiling and/or toxigenic food-related fungi (VELLUTI et al., 2003; FENG; ZENG, 2007; OMIDBEYGI et al., 2007). Phyto-compounds are expected to be far more advantageous than synthetic antifungals for sheer magnitudes of complexity, diversity and novelty of chemicals and reactions since they are bio-degradable in nature, non-pollutant, and posses no residual properties (SHARMA; TRIPATHI, 2008).

The genus Origanum, Labiateae, is an annual, perennial, and shrubby herb that is native to the Mediterranean, Euro-Siberian, and Irano-Siberian regions. Origanum species grow abundantly on stony slopes and rocky mountain areas at a wide range of altitudes (0-400 m) (SAHIN et al., 2004). Origanum vulgare L. is widely known as a very versatile plant with many therapeutic properties (diaphoretic, carminative, antispasmodic, antiseptic, tonic) being applied in traditional medicine systems in many countries (SAGDIÇ et al., 2002; CHUN et al., 2005). It has been widely used in agricultural, and perfumery for its spicy fragrance (SOUZA; STAMFORD; LIMA, 2006; SOUZA et al., 2007).

$O$. vulgare has presented interesting results in inhibiting the growth of bacteria, fungi, and the synthesis of microbial metabolites (MARINO; BERSANI; COMI, 2001; BAYDAR et al., 2004). O. vulgare is rich in essential oil characterized for high amount of phenolic compounds which are believed to be responsible for their antimicrobial property (SKANDAMIS; TSIGARIDA; NICHAS, 2002; FERRARA; MONTESANTO; CHIANTESE, 2003).

This study aimed to evaluate the effect of $O$. vulgare essential oil on various aspects related to the growth/survival and morphogenesis of some food related potentially toxigenic Aspergillus species. To our knowledge, the effect of $O$. vulgare essential oil on the morphology of Aspergillus genus has not been reported to date.

\section{Materials and methods}

\subsection{Essential oil}

The essential oil (batch 209, November/2006) was obtained from Ferquima Ind. e Com. Ltda. (Vargem Grande Paulista, São Paulo, Brazil), and its quality parameters (appearance, color, purity, odor, density $-20^{\circ} \mathrm{C}$, refraction index $-20^{\circ} \mathrm{C}$ ) were described in a accompanying technical report. The essential oil was assayed under concentrations ranging from 80 to $0.3 \mu \mathrm{L} \cdot \mathrm{mL}^{-1}$. Essential oil solutions were prepared in Sabouraud broth using bacteriological $\operatorname{agar}\left(0.15 \mathrm{~g} .100, \mathrm{~mL}^{-1}\right)$ as stabilizing agent according to Mann and Markam (1998) and Bennis et al. (2004).

\subsection{Moulds strains}

Aspergillus flavus ATCC 6013, A. flavus ATCC 40640, A. ochraceus ATCC 22947, A. parasiticus NRRL 2999,
A. fumigatus ATCC 40640, and A. terreus ATCC 7860 were used as test microorganisms. These strains were obtained through the courtesy of the Laboratory of Mycology, Federal University of Paraíba, João Pessoa, Paraíba, Brazil. The stock cultures were kept on sterile Sabouraud Agar (SA) slants under $8{ }^{\circ} \mathrm{C}\left( \pm 1^{\circ} \mathrm{C}\right)$. For anti-mould assays, 7 day-old culture grown on sterile $\mathrm{SA}$ at $25-28^{\circ} \mathrm{C}$ were used. Mould spores were taken by adding sterile $\mathrm{NaCl}\left(0.85\right.$ g. $\left.100 \mathrm{~mL}^{-1}\right)$ to the medium followed for gentle shaking for 30 seconds. Each suspension was filtered through a sterile triple layer cheesecloth to remove mycelial fragments. The mould spores were counted using a hemocytometer. The spore suspension was adjusted using sterile $\mathrm{NaCl}\left(0.85 \mathrm{~g} .100 \mathrm{~mL}^{-1}\right)$ to contain approximately $10^{6}$ spores. $\mathrm{mL}^{-1}$ (RASOOLI; ABYANEH, 2004; RASOOLI; OWLIA, 2005).

\subsection{Determination of the Minimum Inhibitory Concentration (MIC) and Minimum Fungicidal Concentration (MFC)}

MIC and MFC were determined by macrodilution in broth. $5 \mathrm{~mL}$ of double strength Sabouraud Broth (SB) was inoculated with $1 \mathrm{~mL}$ of the mould suspension (approximately $10^{6}$ spores. $\mathrm{mL}^{-1}$ ). Next, $4 \mathrm{~mL}$ of the essential oil solution with different concentrations was added to the system and followed by shaking for 30 seconds using a Vortex. The system was incubated for $48-72$ hours at $25-28{ }^{\circ} \mathrm{C}$ without shaking. The MIC was defined as the lowest concentration of the essential oil required to completely prevent visible fungal growth. An aliquot $(1 \mathrm{~mL})$ of the tubes showing no visible mould growth was subcultured on sterile SA Petri dishes at $25-28^{\circ} \mathrm{C}$ for 72 hours to determine if the inhibition was reversible or permanent. The MFC was defined as the lowest concentration of the essential oil at which no growth was noted on SA. The control flasks without essential oil were tested in the same way (RASOOLI; ABYANEH, 2004; SHARMA; TRIPATHI, 2008).

\subsection{Measure of radial mycelial growth}

The inhibition of the essential oil on the radial mycelial growth was determined using the poisoned substrate technique (dilution in solid medium). For this, a $2 \mathrm{~mm}$ plug taken from a 10 day-old mould culture grown on SA slants at $25-28^{\circ} \mathrm{C}$ was placed on the center of sterile SA Petri dishes added with $2.5,1.25$ and $0.6 \mu \mathrm{L} . \mathrm{mL}^{-1}$ of the oil at $25-28^{\circ} \mathrm{C}$. At different intervals $(0,2$, $4,6,8,10,12$ and 14 days) after incubation, the radial mycelial growth was measured $(\mathrm{mm})$ using calipers. The control flasks without the essential oil were tested in the same way (ADAM et al., 1998; DAFERERA; ZIOGAS; POLISSIOU, 2003).

\subsection{Determination of mycelial dry weight}

The inhibition of the essential oil on the mycelial dry weight was determined using the poisoned substrate technique (dilution in liquid medium). Hence, $10^{6}$ spores. $\mathrm{mL}^{-1}$ of the assayed fungi was inoculated in sterile SB Erlenmeyer flasks added with the essential oil at concentrations of $1.25,0.6$ and $0.3 \mu \mathrm{L} \cdot \mathrm{mL}^{-1}$. After 15 days of incubation, the dry weight of the mycelium was determined. Flasks containing mycelia were autoclaved $\left(121^{\circ} \mathrm{C}\right.$ for 30 seconds) in order to inactivate the spores. Thereafter, the content of the flasks were filtered by 
Whartman filter $\mathrm{n}^{\circ} .1$ and washed twice with sterile distilled water. Mycelia were allowed to dry at $60^{\circ} \mathrm{C}$ for 6 hours and then at $40^{\circ} \mathrm{C}$ overnight. The filter paper containing dry mycelia was weighed. The control flasks without essential oil were tested in the same way. The percentage of mycelia growth inhibition in terms of dry weight was calculated in comparison with the control assay (RASOOLI; REZAEI; ALLAMEH, 2006).

\subsection{Mould spores viability}

$5 \mathrm{~mL}$ of sterile double strength SB were inoculated with $1 \mathrm{~mL}$ of the mould suspension (approximately $10^{6}$ spores. $\mathrm{mL}^{-1}$ ). Next, $4 \mathrm{~mL}$ of the essential oil solution (1.25 and $\left.0.25 \mu \mathrm{L} \cdot \mathrm{mL}^{-1}\right)$ were added to the system and followed for shaking using a Vortex for 30 seconds. The system was incubated at $28-30^{\circ} \mathrm{C}$. At different time intervals $(0,15,30,45,60$, and 120 minutes) of postincubation, $1 \mathrm{~mL}$ of the suspension was serially diluted in PBS $\left(10^{-1}-10^{-4}\right)$, spread on sterile SA Petri dishes, and incubated for $28-30^{\circ} \mathrm{C} / 48-72$ hours. The control flasks without the essential oil were tested in the same way. After the incubation time, the mean number of Colonies Forming Unities (cfu.mL ${ }^{-1}$ ) was counted. The percentage of inhibition of spore viability was calculated in comparison with the control assay (RASOOLI; REZAEI; ALLAMEH, 2006; TZORTZAKIS; ECONOMAKIS, 2007).

\subsection{Spore germination assay}

Aliquots of $0.1 \mathrm{~mL}$ of the essential oil at concentrations of $10,5,2.5$, and $1.25 \mu \mathrm{L} \cdot \mathrm{mL}^{-1}$ were mixed with $0.1 \mathrm{~mL}$ of mould spore suspension (approximately $10^{6}$ spores. $\mathrm{mL}^{-1}$ ). The mixture was placed on separated glass slides which were incubated in a moist chamber at $25-28{ }^{\circ} \mathrm{C}$ for 24 hours. At the end of the incubation period, each slide was fixed with lacto-phenolcotton blue stain and observed under a light microscope for spore germination. Control flasks without essential oil were tested in the same way. About 200 spores were counted and the percentage of spore germination was calculated in comparison with the control assay (FENG; ZENG, 2007).

\subsection{Fungal morphogenesis study}

For the evaluation of morphological alterations caused by the essential oil $\left(2.5 \mu \mathrm{L} . \mathrm{mL}^{-1}\right)$ in A. parasiticus NRRL 2999, a sample of mycelium was taken from the periphery of a 10-day-old fungal colony grown on SA at $25-28^{\circ} \mathrm{C}$ containing the essential oil. The samples were fixed in lacto-phenol-cotton blue stain and observed under a microscope at $400 \times$ to examine morphological abnormalities. The samples from the control SA plates without the essential oil were also stained and their morphological aspects were observed (SHARMA; TRIPAPHI, 2008).

\section{Results and discussion}

O. vulgare L. essential oil showed broad anti-mould spectrum against all investigated fungi. The MIC and MFC values of $O$. vulgare essential oil on potentially toxigenic foodrelated Aspergillus species in liquid medium are shown in Table 1. The MIC was $0.6 \mu \mathrm{L} \cdot \mathrm{mL}^{-1}$ for all fungi. The MFC was in the range of $1.25-2.5 \mu \mathrm{L} \cdot \mathrm{mL}^{-1}$. The MFC of $2.5 \mu \mathrm{L} \cdot \mathrm{mL}^{-1}$ was found to A. parasiticus and A. terreus.
Velluti et al. (2003) found significant inhibitory effect of $O$. vulgare essential oil at 500 and $1000 \mu \mathrm{g} . \mathrm{g}^{-1}$ against the growth of Fusarium proliferatum and production of fumonisin $B_{1}$ in maize grains. Sahin et al. (2004) found MIC values of O. vulgare ssp. vulgare essential oil of 125 and $31.25 \mu \mathrm{L} \cdot \mathrm{mL}^{-1}$ toward A. flavus and A. versicolor, respectively.

The effect of $O$. vulgare essential oil on the radial mycelial growth of A. flavus and A. parasiticus in solid medium is shown in Figures 1 and 2. The essential oil at 0.6, 1.25, and $2.5 \mu \mathrm{L} \cdot \mathrm{mL}^{-1}$ exhibited a fumigant effect against both fungi. $O$. vulgare provided a $100 \%$ of lethal effect against A. flavus after 2 days. A. parasiticus presented a light increase in the radial growth up to 8 days of exposure to 1.25 and $0.6 \mu \mathrm{L} \cdot \mathrm{mL}^{-1}$ of the oil. However, the growth was always smaller than that of the control assay. These findings show a cidal property of the assayed essential oil providing a fast and steady rate of mycelial growth inhibition.

The effect of $O$. vulgare essential oil on the dry micelyal mass weight of Aspergillus species in liquid medium is shown in Table 2. The oil at all tested concentrations $(1.25,0.6$ and $0.3 \mu \mathrm{L} \cdot \mathrm{mL}^{-1}$ ) caused a $100 \%$ inhibition of the biomass of $A$. flavus and A. terreus. For A. fumigatus, A. prasiticus, and A. ochraceus the biomass inhibition was between 91 and 100\% showing dependence of the assayed concentration. The inhibition percentage in terms of radial growth and dry weight showed similar efficacy of the oil in solid and liquid medium.

Table 1. MIC and MFC of the O. vulgare L. on potentially toxigenic Aspergillus species.

\begin{tabular}{lcccc}
\hline \multicolumn{1}{c}{ Moulds } & $\begin{array}{c}\text { MIC } \\
\left(\mu \mathrm{L} \cdot \mathrm{mL}^{-1}\right)\end{array}$ & $\begin{array}{c}\text { MFC } \\
\left(\mu \mathrm{L} \cdot \mathrm{mL}^{-1}\right)\end{array}$ & $\begin{array}{c}\text { Control } \\
\begin{array}{c}\text { Mould } \\
\text { viability }\end{array}\end{array}$ \\
\hline A. flavus ATCC 6013 & 0.6 & 1.25 & + & + \\
A. fumigatus ATCC 40640 & 0.6 & 1.25 & + & + \\
A. parasiticus NRRL 2999 & 0.6 & 2.5 & + & + \\
A. ochraceus ATCC 22947 & 0.6 & 1.25 & + & + \\
A. terreus ATCC 7860 & 0.6 & 2.5 & + & + \\
\hline
\end{tabular}

${ }^{*}$ Mould growth in Sabouraud agar without adding the essential oil.

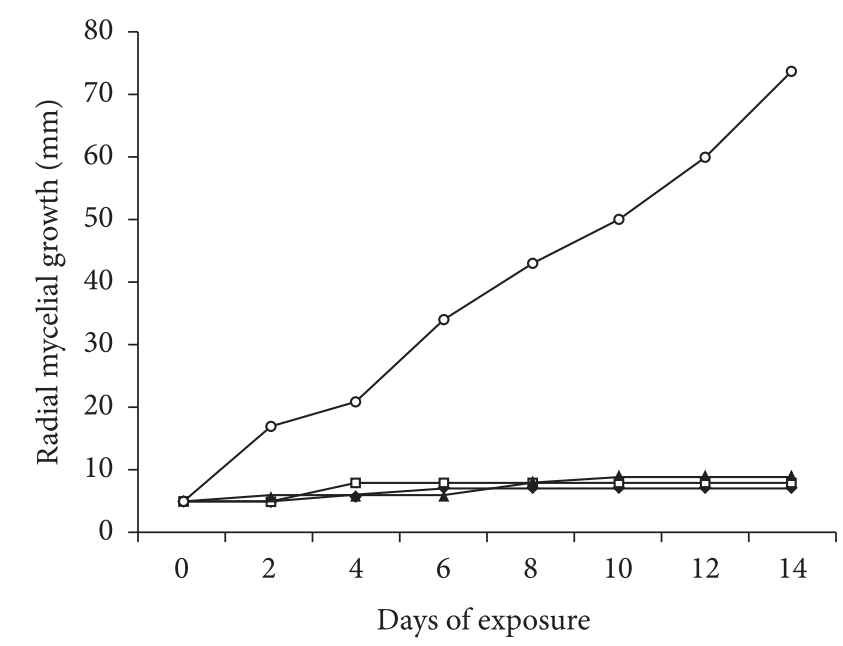

$\rightarrow 2.5 \mu \mathrm{L} \cdot \mathrm{mL}^{-1} \rightarrow 1.25 \mu \mathrm{L} \cdot \mathrm{mL}^{-1} \rightarrow 0.6 \mu \mathrm{L} \cdot \mathrm{mL}^{-1} \multimap$ Control

Figure 1. Effect of O. vulgare L. essential oil on the radial mycelial growth of A. flavus ATCC 6013. 


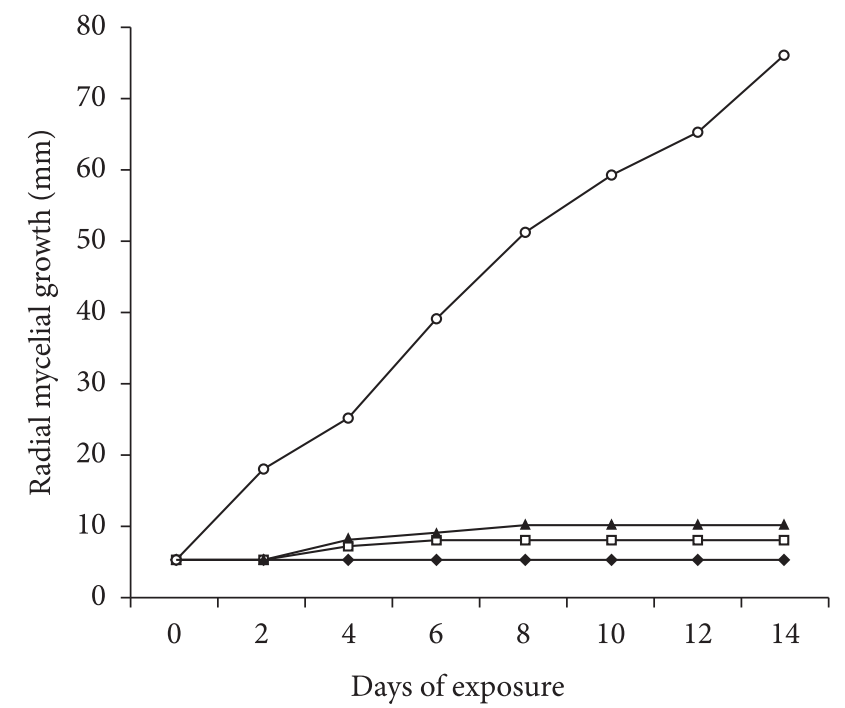

$\multimap 2.5 \mu \mathrm{L} \cdot \mathrm{mL}^{-1} \rightarrow-1.25 \mu \mathrm{L} \cdot \mathrm{mL}^{-1} \rightarrow 0.6 \mu \mathrm{L} \cdot \mathrm{mL}^{-1} \multimap-$ Control

Figure 2. Effect of $O$. vulgare L. essential oil on the radial mycelial growth of A. parasiticus NRRL 2999.

The effect of $O$. vulgare L. essential oil ( 0.6 and $\left.1.25 \mu \mathrm{L} . \mathrm{mL}^{-1}\right)$ on the spore viability of A. flavus ATCC 6013 and A. parasiticus NRRL 2999 in liquid medium revealed over 80\% inhibition after 120 minutes of exposure in comparison with the control assay. It was found that the oil at $1.25 \mu \mathrm{L} \cdot \mathrm{mL}^{-1}$ caused a $100 \%$ inhibition of the spore viability of both fungi in a maximum time of 30 minutes (data not showed).

A few studies have focused on the effect of essential oils on the viability of mould spores. Rasooli and Abyaneh (2004) noted no viability of spores of $A$. parasiticus after treating with thyme (Thyme eriocalyx and Thyme $x$-porlock) essential oils $(1 / 4 \mathrm{v} / \mathrm{v})$ for 120 minutes. Rasooli, Rezaei and Allameh (2006) found a decrease in the viability of $A$. niger spores exposed to 250 and $500 \mathrm{ppm}$ of Thyme eriocalyx and Thyme $x$-porlock essential oils.

The results of the effect of $O$. vulgare essential oil at concentrations of $10,5,2.5$, and $1.25 \mu \mathrm{L} . \mathrm{mL}^{-1}$ on the spore germination of $A$. parasiticus NRRL 2999 in liquid medium are shown in Table 3. As can be noted, the essential oil exhibited a $96 \%$ inhibition of spore germination at $10 \mu \mathrm{L} \cdot \mathrm{mL}^{-1}$ concentration, while it was in the range of $25-46 \%$ at 5, 2.5 and $1.25 \mu \mathrm{L} \cdot \mathrm{mL}^{-1}$.

In agreement with previous studies, the inhibition of spore germination caused by $O$. vulgare essential oil was in a dosage response manner (RANA; SINGH; TANEJA, 1997; TZORTZAKIS; ECONOMAKIS, 2007). Sharma and Tripathi (2008) reported a 100 and $50 \%$ inhibition of germination of A. niger spores exposed to Citrus sinensis essential oil at 1.5 and $0.3 \mu \mathrm{g} \cdot \mathrm{mL}^{-1}$, respectively.

Observations of $A$. parasiticus under a light microscope at $400 \times$ magnification after exposure to $2.5 \mu \mathrm{L} \cdot \mathrm{mL}^{-1}$ of $O$. vulgare essential oil showed some morphological abnormalities (Figure 3). Microscopic examination of the control mycelium (untreated cell) showed a regular cell structure with homogenous
Table 2. Inhibitory effect of $O$. vulgare L. essential oil on the micelyal mass of potentially toxigenic Aspergillus species (results expressed as percent inhibition of dry mycelial mass in comparison with the control assay).

\begin{tabular}{lccc}
\hline \multicolumn{1}{c}{ Moulds } & \multicolumn{3}{c}{ Essential oil concentration $\left(\mu \mathrm{L} . \mathrm{mL}^{-1}\right)$} \\
\cline { 2 - 4 } & $1.25(\%)$ & $0.6(\%)$ & $0.3(\%)$ \\
\hline A. flavus ATCC 6013 & 100 & 100 & 100 \\
A. fumigatus ATCC 40640 & 100 & 94 & 91 \\
A. parasiticus NRRL 2999 & 100 & 100 & 96 \\
A. ochraceusATCC 22947 & 100 & 100 & 95 \\
A. terreus ATCC 7860 & 100 & 100 & 100 \\
\hline
\end{tabular}

Table 3. Inhibitory effect of $O$. vulgare L. essential oil on the spores germination of A. parasiticus NRRL 2999 (results expressed as percent inhibition of spore germination in comparison with the control assay).

\begin{tabular}{cc}
\hline Essential oil $\left(\mu \mathrm{L} \cdot \mathrm{mL}^{-1)}\right.$ & Inhibition of spores germination $(\%)$ \\
\hline 10 & ${ }^{9} 6$ \\
5 & ${ }^{4} 6$ \\
2.5 & ${ }^{3} 7$ \\
1.25 & ${ }^{2} 5$ \\
\hline
\end{tabular}

cytoplasm, clearly visible sterigmata bearing conidia and profuse conidiation on a large and radiated conidial head. The mycelia cultivated in the medium added with the essential oil appeared to present morphological changes with a heterogeneous mycelial structure. The alterations included lack of sporulation, loss of cytoplasm content (empty hyphae), loss of pigmentation, distorted development hyphae, and empty hyphae. The hyphae became distorted with swelling along its structure and budded apical tips. Still, the oil caused a clear absence of conidiation. Abnormalities in hyphae and spores coloring were not evaluated.

Previous studies reported that essential oils are able to cause morphological changes in Aspergillus species including lack of sporulation, loss of pigmentation, aberrant development of conidiophores (flattened and squashed), and distortion of hyphaes (DE BILLERBERK et al., 2001; RASOOLI; ABYANEH, 2004; SHARMA; TRIPATH, 2008). These findings suggested that the mode of antifungal activity of essential oils could include an attack on the cell wall and retraction of the cytoplasm in the hyphae ultimately resulting in the death of the mycelium. In addition, it was also related to the interference of the essential oil components in enzymatic reactions of cell wall synthesis, which affects the fungal growth and morphogenesis.

Velluti et al. (2003) suggest that the antimicrobial activity of the essential oil depends on the chemical structure of their components. Carvacrol and thymol, phenolic compounds known as major constituents of $O$. vulgare essential oil, have their antimicrobial property attributed to the presence of an aromatic group that is known to be reactive and to form hydrogen bonds with active sites of target enzymes (DIMITRIJEVIĆ et al., 2007; SOUZA et al., 2007). However, it is also suggested that the effectiveness of complete essential oils is higher than the activity of each separated compound (MILOS; MASTELIC; JERKOVIC, 2000). 

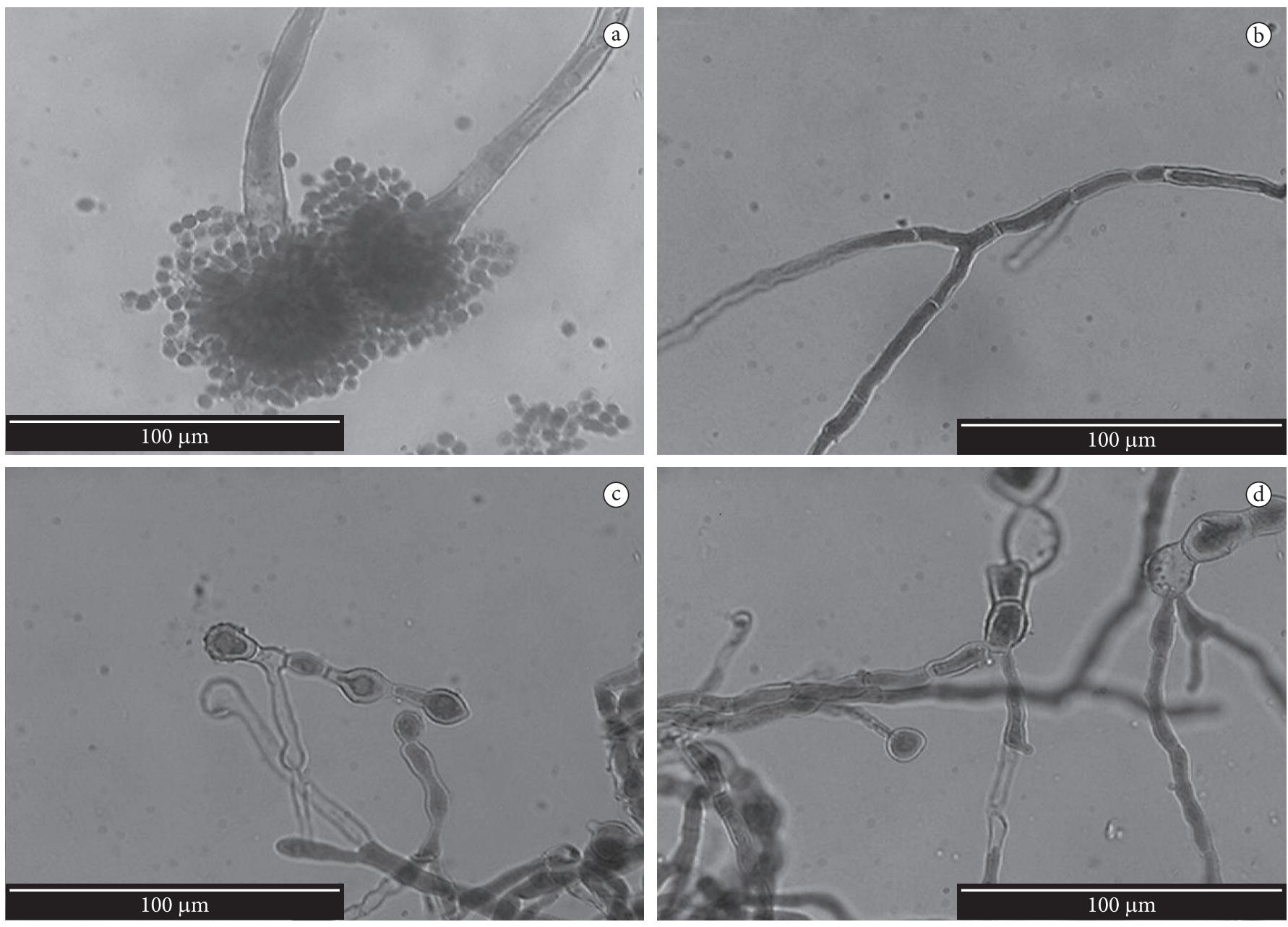

Figure 3. Light microphotographs of A. parasiticus NRRL 2999 mycelium growing on AS without or with O. vulgare essential oil (2.5 $\mu$ L.mL $\left.\mathrm{mL}^{-1}\right)$ during 7 days of incubation at $25-28^{\circ} \mathrm{C}$. a) Control conidial head of $A$. parasiticus, large and radiated, development of vesicle on conidiophore, conidia clearly visible, Bar $100 \mu \mathrm{m}$; b) A. parasiticus control mycelium, homogeneous structure and regular growing hyphae, control magnification of single hyphae, Bar $100 \mu \mathrm{m}$; c-d) Hyphae modification induced by $2.5 \mu \mathrm{L} . \mathrm{mL}^{-1}$ of $O$. vulgare essential oil showing anomalous structure and loss of pigmentation; clear leakage of cytoplasm content and destruction of cell structure noted by disrupted hyphae integrity, Bar $100 \mu \mathrm{m}$; and d) conidial head with clear absence of conidiation, Bar $100 \mu \mathrm{m}$.

The present study confirmed the anti-Aspergillus activity of O. vulgare essential oil based on MIC, MBC, mycelia growth, spore germination/viability, and morphological changes. The assayed essential oil presented a fast and steady fungitoxic property supporting its rational use as an alternative to be applied in the biocontrol of Aspergillus species in foodstuffs.

\section{References}

ADAM, K. et al. Antifungal activities of Origanum vulgare subsp. hirtum, Mentha spicata, Lavandula angustifolia, and Salvia fruticosa essential oils against human pathogenic fungi. Journal of Agricultural and Food Chemistry, v. 46, n. 5, p. 1739-1745, 1998.

ATANDA, O. O.; AKPAN, I.; OLUWAFEMI, F. The potential of some spice essential oils in the controlo f $A$. parasiticus CFR 223 and aflatoxin production. Food Control, v. 18, n. 5, p. 601-607, 2007.

BAYDAR, H. et al. Antibacterial activity and composition of essential oils from Origanum, Thymbra and Sartureja species with commercial importance in Turkey. Food Control, v. 5, n. 3, p. 169-172, 2004.
BENNIS, S. et al. Surface alteration of Saccharomyces cerevisae induced by thymol and eugenol. Letters in Applied Microbiology, v. 38, n. 6, p. $454-458,2004$.

CHUN, S. S. et al. Phenolic antioxidants from clonal oregano (Origanum vulgare) with antimicrobial activity against Helicobacter pylori. Process Biochemistry, v. 40, n. 2, p. 809-816, 2005.

DAFERERA, D. J.; ZIOGAS, B. N.; POLISSIOU, M. G. The effectiveness of plant essential oils on the growth of Botrytis cinerea, Fusarium sp. and Clavicbacter michiganensis subsp. michiganensis. Crop Protection, v. 22, n. 1, p. 39-44, 2003.

DE BILLERBERK, V. G. et al. Effects of Cymbopogon nardus (L.) W. Watson essential oil on the growth and morphogenesis of Aspergillus niger. Canadian Journal of Microbiology, v. 47, n. 1, p. 9-17, 2001.

DIMITRIJEVIĆ, S. I. et al. A study of the synergistic antilisterial effects of a sub-lethal dose of lactic acid and essential oils from Thymus vulgaris L., Rosmarinus officinalis L. and Origanum vulgare L. Food Chemistry, v. 104, n. 2, p. 774-782, 2007.

FENG, W.; ZENG, X. Essential oils to control Alternaria alternate in vitro and in vivo. Food Control, v. 18, n. 9, p. 1126-1130, 2007. 
FERRARA, L. K.; MONTESANTO, D.; CHIANTESE, C. Origanum marjoran L. in medicine and foods. Ingredientia Alimentaria, v. 2, n. 3, p. 23-25, 2003.

KUMAR, R. et al. Evaluation of Cheopodium ambrosioides oil as a potential source of antifungal, antiaflatoxigenic and antioxidant activity. International Journal of Food Microbiology, v. 115, n. 2, p. 159-164, 2007.

MANN, C. M.; MARKHAM, J. L. A new method for determining the minimum inhibitory concentration of essential oils. Journal of Applied Microbiology, v. 84, n. 5, p. 538-544, 1998.

MARINO, M.; BERSANI, C.; COMI, G. Impedance measurements to study the antimicrobial activity of essential oils from Lamiaceae and Compositae. International Journal of Food Microbiology, v. 67, n. 3, p. 187-195, 2001.

MILOS, M.; MASTELIC, J.; JERKOVIC, L. Chemical composition and oxidant effect of glicosidically bound volatile compounds from Oregano (Origanum vulgare L. spp. hirtum). Food Chemistry, v. 71, n. 6, p. 79-83, 2000.

OMIDBEYGI, M. et al. Antifungal activity of thyme, summer savory and cloves essential oil against Aspergillus flavus in liquid medium and tomate paste. Food Control, v. 18, n. 12, p. 1518-1523, 2007.

OVERY, D. P. et al. Spoilage fungi and their mycotoxins in commercially marketed chestnuts. International Journal of Food Microbiology, v. 88 , n. 1, p. 69-77, 2003.

RANA, B. K.; SINGH, U. P.; TANEJA, V. Antifungal activity and kinetics of inhibition by essential oil isolated from leaves of Aegle marmelos. Journal of Ethnopharmacology, v. 57, n. 1, p. 29-34, 1997.

RASOOLI, I.; ABYANEH, M. R. Inhibition effects of Thyme oils on growth and aflatoxin production by Aspergillus parasiticus. Food Control, v. 15, n. 6, p. 479-483, 2004.

RASOOLI, I.; OWLIA, P. Chemoprevention by thyme oils of Aspergillus parasiticus growth and aflatoxin production. Phytochemistry, v. 66, n. 24, p. 2851-2856, 2005.

RASOOLI, I.; REZAEI, M. B.; ALLAMEH, A. Growth inhibition and morphological alterations of Aspergillus niger by essential oils from Thymus eriocalyx and Thymus $x$-porlock. Food Control, v. 17, n. 5, p. 359-364, 2006.
SAGDIÇ, O. et al. Effects of Turkish spices extracts at various concentrations on the growth of Escherichia coli O157:H7. Food Microbiology, v. 19, n. 5, p. 473-480, 2002.

SAHIN, F. et al. Biological activities of the essential oils and methanol extract of Origanum vulgare ssp. vulgare in the Eastern Anatolia region of Turkey. Food Control, v. 15, n. 7, p. 549-557, 2004.

SALEEMULLAH, A. I.; KHALIL, I. A.; SHAH, H. Aflatoxin contents of stored and artificially inoculated cereals and nuts. Food Chemistry, v. 98, n. 4, p. 699-703, 2006.

SAMAPUNDO, S. et al. Can phenolic compounds be used for the protection of corn from fungal invasion and mycotoxin contamination during storage? Food Microbiology, v. 24, n. 5, p. $465-473,2007$.

SHARMA, N.; TRIPATHI, A. Effects of Citrus sinensis (L.) Osbeck epicarp essential oil on growth and morphogenesis of Aspergillus niger (L.) Van Tieghem. Microbiological Research, v. 163, n. 3, p. 337-344, 2008.

SKANDAMIS, P.; TSIGARIDA, E.; NICHAS, G. J. E. The effect of oregano essential oil on survival/death of Salmonella typhimurium in meat stored at $5^{\circ} \mathrm{C}$ under aerobic, VP/MAP conditions. Food Microbiology, v. 19, n. 1, p. 97-108, 2002.

SOUZA, E. L. et al. Effectiveness of Origanum vulgare L. essential to inhibit the growth of food spoiling yeasts. Food Control, v. 18, n. 5, p. 409-413, 2007.

SOUZA, E. L.; STAMFORD, T. L.; LIMA, E. O. Sensitivity of spoiling and pathogen-food related bacteria to Origanum vulgare $\mathrm{L}$. (Lamiaceae) essential oil. Brazilian Journal of Microbiology, v. 37, n. 4, p. 527-532, 2006.

TZORTZAKIS, N. G.; ECONOMAKIS, C. D. Antifungal activity of lemongrass (Cymbopogon citratus L.) essential oil against key postharvest pathogens. Innovative Food Science and Emerging Technologies, v. 8, n. 2, p. 253-258, 2007.

VELLUTI, A. et al. Inhibitory effect of cinnamon, clove, lemongrass, oregano and palmarose essential oils on growth and fumonisin production by Fusarium proliferatum in maize grains. International Journal of Food Microbiology, v. 89, n. 2-3, p. 145-154, 2003. 